\title{
THE DURABILITY OF HYGRO-IMMERSION AGED CELLULOSE FIBRE REINFORCED POLYMER LAYERED SILICATE NANOCOMPOSITES
}

\author{
C. S. Suhas Kowshik ${ }^{1}$, Nanjangud Mohan ${ }^{1}$, Nithesh NaIK ${ }^{1}$, Manjunath \\ SHETTAR $^{1}$, RITESH BHAT $^{{ }^{*}}{ }^{*}$ AND SHIVAKSH ROHATGI ${ }^{2}$ \\ ${ }^{1}$ Department of Mechanical and Manufacturing Engineering, Manipal Institute of Technology, \\ Manipal Academy of Higher Education, Manipal, India 576104 \\ ${ }^{2}$ Department of Propulsion Aeronautics and Space Engineering, École Centrale de Lyon, \\ Écully, France 69134 \\ "Corresponding author: ritesh.bhat@manipal.edu
}

(Received: 19th August 2020; Accepted: $21^{\text {st }}$ October 2020; Published on-line: $4^{\text {th }}$ January 2021)

\begin{abstract}
This study aims at investigating the effect of water ageing on the durability of cellulose fibre reinforced polymer layered silicate nanocomposite. The material used comprises cellulose fibres from pinewood as reinforcement and high-density polyethene (HDPE) coupled with nanoclay as matrix phase. The prepared material is subjected to tap water ageing for 21 days. The durability is quantified by Barcol hardness for the material and measured at an interval period of 7 days. The obtained results indicate a reduction of hardness by $5.24,13.17$, and $16.60 \%$ in 7,14 , and 21 days aged nanocomposites. Besides, the one-way ANOVA test shows that the immersion time for the composite has a significant effect on the durability of the material with an $\mathrm{R}^{2}$ value of $99.96 \%$ tested at $95 \%$ confidence interval. The concluding remarks are validated using the results obtained for thickness swelling using the Fourier analysis. The work also presents a regression equation with high degree of accuracy, capable of estimating the Barcol hardness value for a given immersion time.
\end{abstract}

ABSTRAK: Kajian ini bertujuan untuk mengkaji kesan penuaan air terhadap ketahanan nanokomposit silikat berlapis polimer bertetulang serat selulosa. Bahan yang digunakan terdiri daripada serat selulosa dari kayu pina sebagai tetulang dan polietena berketumpatan tinggi (HDPE) ditambah dengan nanoclay sebagai fasa matriks. Bahan yang disediakan mengalami penuaan air paip selama 21 hari. Ketahanan diukur dengan kekerasan bahan Barcol dan diukur pada selang waktu 7 hari. Hasil yang diperoleh menunjukkan penurunan kekerasan sebanyak 4.74, 8.88 dan 18.90\% dalam nanokomposit usia 7, 14 dan 21 hari. Selain itu, analisis satu arah ujian varians menunjukkan bahawa masa rendaman komposit mempunyai pengaruh yang signifikan terhadap ketahanan bahan dengan nilai $\mathrm{R}^{2} 99.96 \%$ yang diuji pada selang keyakinan 95\%. Ucapan penutup disahkan menggunakan hasil yang diperoleh untuk pembengkakan ketebalan menggunakan analisis Fourier. Karya ini juga menyajikan persamaan regresi dengan tahap ketepatan yang tinggi, yang dapat menganggarkan nilai kekerasan Barcol untuk masa rendaman tertentu.

KEYWORDS: mechanical property; nanocomposites; natural fibres; polymers; ANOVA

\section{INTRODUCTION}

The usage of modified polymer layered silicate as matrix phase, comprising a base thermoplastic resin and clay as the primary elements have been proven to improve the mechanical and thermal properties of nanocomposites. Besides, they are determined to be 
lighter in weight and have excellent barrier properties compared to simple polymer composites [1].

Polyethene, polythene, or polyethylene is a known polymer that accounts for one-third of the world's total plastic production and is generally compounded with natural minerals to enhance its properties, dimensional stability, and electric insulation properties while being used in composites. The compounding of clay with polythene has been proven by researchers [2] to improve exfoliation. Improved exfoliation ought to improve the mechanical performance of the polymer layered silicate matrix nanocomposites. Amongst polyethene, high-density polyethene (HDPE) has been considered as a prime base resin for its ease of availability and recyclability compared to other counterparts.

Furthermore, the addition of clay to the HDPE intends to improve the toughness of prepared nanocomposites [3-4]. Addition of nanoclay to HDPE has been proven to reduce gas permeability while increasing mechanical properties, flame retardance, and thermal stability [5]. During the last few years, cellulose fibre reinforced polymer composites have emerged as a significant class of advanced engineering materials and have found a wide range of applications. Moreover, the cellulose fibre reinforced polymer layered silicate nanocomposite outperforms natural wood in flexural properties [6]. Thus, cellulose fibre reinforced polymer layered silicate nanocomposites with HDPE as base resin coupled with nanoclay, and cellulose fibres as reinforcements, have been a topic of interest for various researchers. For example, Delhom et al. [7] investigated the tensile strength, flame retardance, and thermal expansion of cellulose fibre reinforced polyethene layered silicate nanocomposites. Authors extracted the cellulose fibres from cotton lint and wood pulp. Three variants were studied based on the varying percentages of clay by weight $(7,10$, and $15 \%$ ). The results indicated nanocomposites with $7 \mathrm{wt} \%$ of clay is optimum considering the thermal properties. However, considering the mechanical properties, the nanocomposites comprising $15 \mathrm{wt} \%$ of clay proved better as the ultimate tensile strength increased by $80 \%$. Sheshmani et al. [8] examined the physical properties of the developed cellulose fibre reinforced polymer layered silicate nanocomposite. The authors used HDPE as base resin coupled with montmorillonite nanoclay to form the matrix with wood fibres as the reinforcement. The result indicated an improvement in the resistance offered to water uptake by the developed nanocomposite over the conventional wood-plastic composites. On a similar account, Deka and Maji [9] in their extensive experimental work, coupled the Montmorillonite nanoclay with several variants and polymers to develop different cellulose fibre reinforced nanocomposites. They investigated the post and pre-effect of the addition. The results indicated that the addition of nanoclay improved thermal stability, flame resistance, hardness, and resistance to water absorption, compared to conventional wood plastic composites.

Hossen et al. [10] investigated the mechanical and physical properties of cellulose fibre reinforced HDPE layered silicate nanocomposites, wherein the cellulose fibres used were from jute fibres. The result indicated an improvement by $8 \%$ in the tensile strength and $15 \%$ in modulus when compared to the composites without nanoclay. Eshraghi et al. [11] investigated the combined effect of ultraviolet and moisture on the mechanical and physical properties of the cellulose fibre reinforced HDPE layered silicate nanocomposites. The obtained results indicated the nanocomposites having nanoclay particles demonstrated an improvement in the tensile property as well as in the resistance to water uptake under ageing condition compared to the counterpart. Besides, the Fourier transform infrared spectroscopy indicated the lowest carboxy index in the case of cellulose fibre reinforced HDPE layered silicate nanocomposites. Hossen et al. [12] investigated the thermal behaviour of cellulose fibre reinforced HDPE layered silicate nanocomposites, wherein the cellulose fibres used 
were from the jute fibres. The result indicated a decrease in thermal degradation in the developed nanocomposites when compared to the composites without nanoclay.

El-Fattah and El-Kader [13] demonstrated in their work the influence of nanoclay addition on the mechanical and water absorption properties of cellulose fibre reinforced HDPE layered silicate nanocomposites. With just $2 \%$ addition of clay, the tensile strength improved by $9.7 \%$ and resistance to water uptake enhanced by $27.5 \%$. The research is neverexhausting and several researchers, even to this date, are working on cellulose fibre reinforced HDPE layered silicate nanocomposites. For example, Wang et al. [14] in their research work proved that the tensile properties of cellulose fibre reinforced polymer composites enhances with the addition of the nanoclay in it.

Hossen et al. [15] assessed the thermal and mechanical behaviour of chemically treated cellulose fibre reinforced HDPE composites with and without nanoclay addition. The results indicated the improvement in thermomechanical properties with the addition of nanoclay. From the literature reviewed, it is evident that the cellulose fibre reinforced HDPE layered silicate nanocomposite is a hot topic of research. Though a good amount of research has been conducted on the thermal, mechanical, physical, and microstructural characterisation of the said material, there is a requirement of checking the durability concerning the hardness change due to water immersion effect on the same. Besides, the cellulose fibres from pinewood have rarely been used and investigated concerning the cellulose fibre reinforced HDPE layered silicate nanocomposites. Thus, adding to the existing literature, the present work focuses on investigating the effect of water immersion on the durability concerning the hardness and of cellulose fibre reinforced HDPE layered silicate nanocomposites, wherein pine wood fibres are used. The results are validated by observing the thickness swelling in nanocomposites. The prepared nanocomposites are immersed in tap water for 21 days, and required responses are measured periodically at an interval of seven days. The one-way analysis of variance (ANOVA) is then used to validate the results statistically.

\section{MATERIALS AND METHODS}

\subsection{Materials and Aging Process}

The cellulose fibre reinforced polymer layered silicate is used in the presented study. High density polyethene (HDPE) having a melt flow of $0.7 \mathrm{~g} / \mathrm{min}$ at $190{ }^{\circ} \mathrm{C}$ and density of $0.962 \mathrm{~g} / \mathrm{cc}$ was employed as the base resin. Finely powdered pine wood (40 mesh size) was used as the reinforcement phase. The montmorillonite nanoclay is also added to make the complete nanocomposite. The cellulose-based nanocomposite comprised $65 \mathrm{wt} \%$ of reinforcing pine wood powder, $20 \mathrm{wt} . \%$ of HDPE and $14 \mathrm{wt} \%$ of montmorillonite nanoclay and looked just like natural wood. The density was measured for five samples using the ASTM D2395-17 standard, and the average value was determined to be $695 \mathrm{~kg} / \mathrm{m}^{3}$. The average maximum tensile strength of five specimens as per ASTM D638-14 standard is determined to be $18 \mathrm{MPa}$. Nine samples measuring $100 \times 65 \times 16 \mathrm{~mm}$ were prepared for ageing studies. The materials were then submerged in a tub comprising tap water and allowed to age for the required number of days (7,14 and 21). The marking was made on the tub to prevent any confusion. Fig. 1 represents the cross-sectional view of the prepared specimen and Fig. 2 represents the arrangement of submerged material in the tub with days and batch marked on it. 


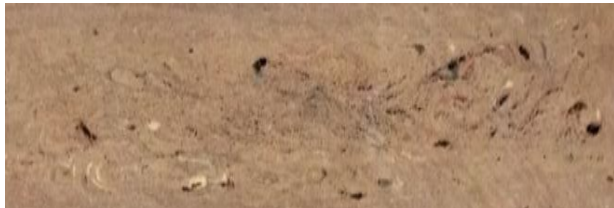

Fig. 1. The cross-sectional view of the prepared specimen.

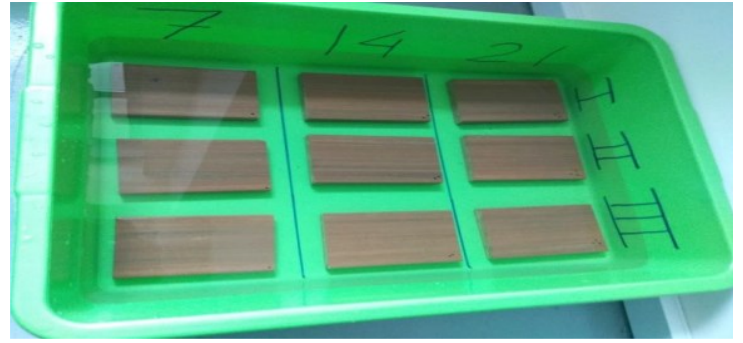

Fig. 2. Cellulose fibre reinforced HDPE

layered silicate nanocomposites immersed in water for ageing.

\subsection{Experimental Procedures}

Hardness is defined as the resistance of any material to the local deformation caused due to the indentation of the predetermined geometry under known loading conditions [16]. Hardness is a function of ductility, elastic stiffness, plasticity, strain, strength, toughness, viscoelasticity, and the viscosity [17]. It is an important property to be studied as it acts as the base for discussing the tribological characteristics of materials [18]. Thus, the study is focused on evaluating the effect of ageing on the hardness of the material. For this purpose, the Barcol hardness test on the specimens is carried out as per the ASTM D2583-95 standard test method of testing the indentation hardness of the rigid polymer composite material using the portable Barcol impressor model 945 (meant for softer materials). The hardness of the material corresponds to the depth of penetration of the indentor. Since the specimens are heterogeneous, a minimum of 25 readings was taken on each of the specimens, and the average value was recorded as the final value. Besides, all the readings were taken at $3 \mathrm{~mm}$ away from the edges. The apparatus was well-calibrated initially as per the standard operating procedure, before all the testing.

Besides hardness, yet another important property of interest, particularly in cellulosebased composites, is the thickness swelling in composite due to water absorption. The thickness swelling in composites represents the stability performance of the composite materials [19], [20]. Thus, to determine the effect of ageing on thickness swelling behaviour of the nanocomposites, the thickness of the specimen was measured daily (gap of $24 \mathrm{~h}$ ) using digital Vernier calliper 1112-150 by INSIZE to get the precise reading up to two decimal values. The materials were removed and wiped with a clean, dry cloth before measuring. Since both sides of the specimen were not coated and were completely immersed in water, the ageing can be considered as accelerated and the worst-case scenario. The thickness swelling was measured for five zones for each specimen, and the average value was considered as the final value of swollen thickness for the particular specimen.

A large number of readings were taken to eliminate the effect of the variances caused by the inhomogeneous nature of the material. ANOVA is a widely used technique for univariate data. It is a basic tool in many fields of research as it determines and quantifies the effect of experimental factors on the observed outcome of an experiment [21]. One-way ANOVA is the fundamental model that specifies the common mean value for the observations in a group [22]. Thus, once all the values were recorded, the one-way ANOVA test was conducted to determine the significance of immersion time on the hardness and thickness swelling of the developed cellulose fibre reinforced HDPE silicate layered nanocomposites. Eq. (1) was used to determine the final value of Barcol hardness $\left(\mathrm{HB}_{\mathrm{f}}\right)$ and Eq. (2) was used to calculate the final value of swollen thickness $\left(t_{f}\right)$ for each specimen, where $i=1,2,3 \ldots, 25$ and $j=1,2, . ., 5$. 
The thickness swelling is determined using Eq. (3), wherein $t_{0}$ represents the initial thickness, and $t_{m}$ represents the thickness after ageing. The number of the ageing period is represented by $\mathrm{k}=7,14$, and 21 in Eq. (3).

$$
\begin{aligned}
& H B_{f}=\sum_{i=1}^{25} H B_{i} \\
& t_{f}=\sum_{j=1}^{5} t_{j} \\
& t_{j}=\frac{t_{m k}-t_{0}}{t_{0}}
\end{aligned}
$$

\section{RESULTS AND DISCUSSION}

The recorded values of Barcol hardness for unaged and aged specimen are given by Table 1, Table 2, and Table 3. The average Barcol value for each specimen recorded in the table refers to the average of 25 readings measured on each one of them. Fig. 3. represents the comparison bar chart for the average values of Barcol hardness concerning unaged and aged specimens.

Table 1: Barcol hardness measurement for 7 days aged samples.

\begin{tabular}{ccccc}
\hline $\begin{array}{c}\text { Sample } \\
\text { No. }\end{array}$ & $\begin{array}{c}\text { Average Barcol } \\
\text { hardness for } \\
\text { unaged material } \\
\left(\mathbf{H B}_{\mathbf{0}}\right)\end{array}$ & $\begin{array}{c}\text { Average Barcol } \\
\text { hardness for 7 days } \\
\text { aged material } \\
\left(\mathbf{H B}_{\mathbf{~}}\right)\end{array}$ & $\begin{array}{c}\text { Percentage } \\
\text { change in Barcol } \\
\text { hardness }\end{array}$ & $\begin{array}{c}\text { Average Percentage } \\
\text { change in Barcol } \\
\text { hardness for 7 days aged } \\
\text { material }\end{array}$ \\
\hline 1 & 39.75 & 37.58 & $5.41 \%$ & \\
2 & 39.81 & 37.64 & $5.28 \%$ & $5.24 \%$ \\
3 & 39.75 & 37.75 & $5.03 \%$ & \\
\hline
\end{tabular}

Table 2: Barcol hardness measurement for 14 days aged samples.

\begin{tabular}{ccccc}
\hline $\begin{array}{c}\text { Sample } \\
\text { No. }\end{array}$ & $\begin{array}{c}\text { Average Barcol } \\
\text { hardness for } \\
\text { unaged material } \\
\left(\mathbf{H B}_{\mathbf{0}}\right)\end{array}$ & $\begin{array}{c}\text { Average Barcol } \\
\text { hardness for 14 } \\
\text { days aged material } \\
\left(\mathbf{H B}_{\mathbf{1 4}}\right)\end{array}$ & $\begin{array}{c}\text { Percentage } \\
\text { change in Barcol } \\
\text { hardness }\end{array}$ & $\begin{array}{c}\text { Average Percentage } \\
\text { change in Barcol } \\
\text { hardness for 14 days } \\
\text { aged material }\end{array}$ \\
\hline 1 & 39.75 & 34.50 & $13.21 \%$ & $13.17 \%$ \\
2 & 39.85 & 34.45 & $13.33 \%$ & \\
3 & 39.75 & 34.60 & $12.96 \%$ & \\
\hline
\end{tabular}

Table 3: Barcol hardness measurement for 21 days aged samples.

\begin{tabular}{ccccc}
\hline $\begin{array}{c}\text { Sample } \\
\text { No. }\end{array}$ & $\begin{array}{c}\text { Average Barcol } \\
\text { hardness for } \\
\text { unaged material } \\
\left(\mathbf{H B}_{\mathbf{0}}\right)\end{array}$ & $\begin{array}{c}\text { Average Barcol } \\
\text { hardness for 21 } \\
\text { days aged material } \\
\left(\mathbf{H B}_{\mathbf{2 1}}\right)\end{array}$ & $\begin{array}{c}\text { Percentage } \\
\text { change in Barcol } \\
\text { hardness }\end{array}$ & $\begin{array}{c}\text { Average Percentage } \\
\text { change in Barcol } \\
\text { hardness for 21 days } \\
\text { aged material }\end{array}$ \\
\hline 1 & 39.75 & 33.20 & $16.48 \%$ & $16.60 \%$ \\
2 & 39.85 & 33.15 & $16.60 \%$ & \\
3 & 39.75 & 33.10 & $16.73 \%$ & \\
\hline
\end{tabular}

From the results obtained, it is evident that the durability concerning the Barcol hardness of the developed cellulose fibre reinforced HDPE layered silicate nanocomposite has decreased with the increase in the immersion time. The overall Barcol hardness reduction is determined to be $5.24,13.17$, and $16.60 \%$ for 7,14 , and 21 days aged samples. While observing critically, the maximum damage is caused during the 14 days, wherein the change of hardness between 7 to 14 days is recorded approximately $8 \%$. The hardness 
reduction between the $14^{\text {th }}$ and $21^{\text {st }}$ day is only $3.43 \%$. The same is evident from the bar graph shown in Fig. 3. The average Barcol hardness value of 7 days aged specimen is 37.67 $\mathrm{HB}$ which was reduced to $34.52 \mathrm{HB}$ on the $14^{\text {th }}$ day. However, the average hardness number of 21 days aged material is recorded as 33.150 , which is very near to the $14^{\text {th }}$ day specimen. Thus, it is a clear indication that the maximum degradation has taken place during the initial period and gradually the rate of degradation is reducing. The phenomenon that took place could be divided into two phases. Initially, the water was absorbed by the hygroscopic pine wood material to the maximum possible extent. Following the absorption, the interfacial degradation was caused and increased water absorption further.

The results could be validated by SEM and EDX analysis. Nevertheless, the present work focuses on just investigating the statistically significant effect of ageing on the hardness and thickness swelling of the developed nanocomposite and not the microstructural analysis. Thus the latter portion can be dealt with in detail by researchers in the future. However, the remarks made are validated through the observations made about the thickness swelling due to the ageing effect on the developed nanocomposite.

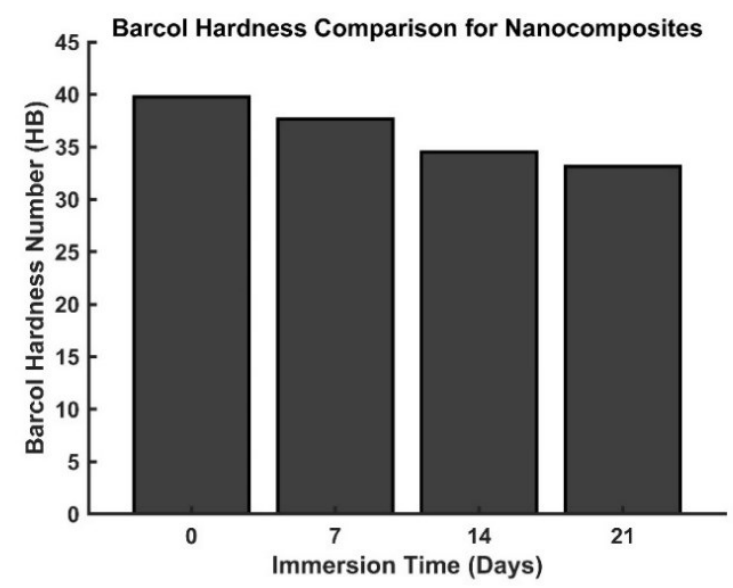

Fig. 3: Comparison of overall hardness values of Barcol hardness for aged and unaged nanocomposites.

The thickness swelling phenomenon in the developed and aged nanocomposites, measured using the digital vernier calliper, was recorded and analysed using the curve fitting tool of MATLAB R2019b. The Fourier equation represented by Eq. (4) is used to fit the curve and predict the thickness for a given period. The goodness of fit is determined to be extremely good with an $\mathrm{R}^{2}$ value of $98.93 \%$ and $\mathrm{R}^{2}(\mathrm{adj})$ value of $98.62 \%$ at a $95 \%$ confidence interval.

$$
f(x)=y=a_{0}+a_{1} \cos (x w)+b_{1} \sin (x w)
$$

The values of $a_{0}, a_{1}, b_{1}$ and $w$ are calculated by the analysis as $16.06,0.006158,0.05883$ and 1.022 respectively. Fig. 4. is the Fourier curve depicting the change in thickness concerning the increase in immersion time. There is a continuous increase in thickness, and then it retains constancy, which can be said as a Fickian behaviour of water absorption. 


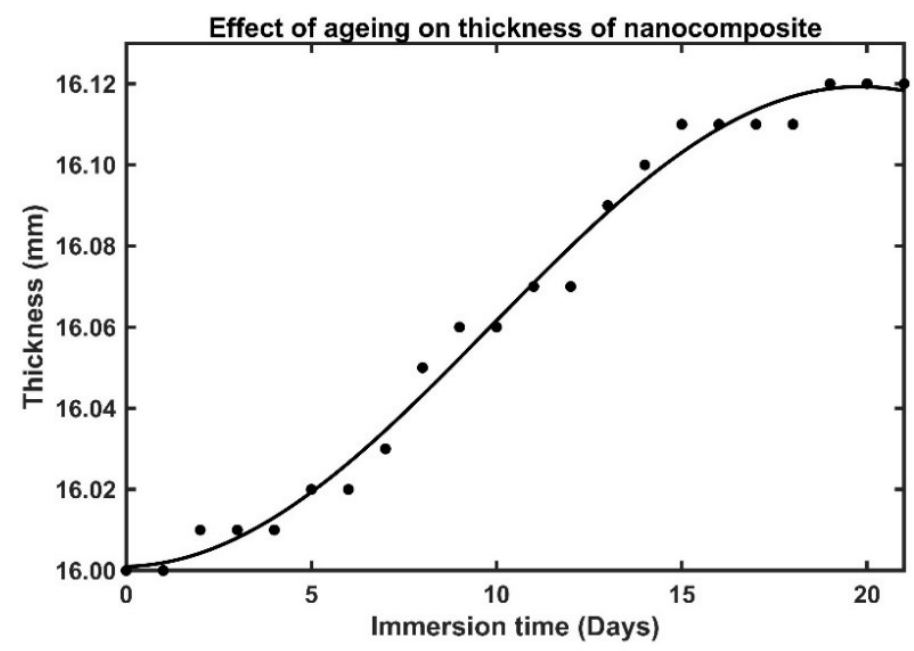

Fig. 4: Fourier curve representing the effect of ageing on the nanocomposite thickness.

The obtained results show that ageing affects the hardness of the developed nanocomposite. Now to check whether the effect is significant, an one-way analysis of variance (ANOVA) test is conducted. Tab. 4 gives the result of ANOVA concerning the hardness of nanocomposite conducted at a $95 \%$ confidence interval.

Table 4: ANOVA results for the hardness of nanocomposite.

\begin{tabular}{cccccccc}
\hline Source & DF & Seq SS & Contribution & Adj SS & Adj MS & F-Value & P-Value \\
\hline Days & 3 & 80.9441 & $99.96 \%$ & 80.9441 & 26.9814 & 6361.03 & 0.000 \\
Error & 8 & 0.0339 & $0.04 \%$ & 0.0339 & 0.0042 & & \\
Total & 11 & 80.9781 & $100.00 \%$ & & & & \\
\hline
\end{tabular}

The p-value of 0.00 indicates that the effect of ageing is highly significant on the change in hardness. The error is just $0.04 \%$. In other words, the immersion time contributes $99.6 \%$ towards the variance in the hardness of the developed composites. Thus, for the nanocomposite developed, the durability concerning the hardness can be termed as the function of immersion time and said to have a significant effect of ageing. Furthermore, the regression analysis is done with a cubic model to obtain the prediction equation relating the immersion time with the hardness value. The obtained equation is represented by Eq. (5), wherein HB represents the Barcol hardness, and the term D represents the immersion time in days. The $\mathrm{R}^{2}$ and the $(\operatorname{adj}) \mathrm{R}^{2}$ values are 99.94 and $99.92 \%$, which represent an extreme degree of fitness and accuracy for the obtained equation.

$$
H B=39.77-0.09700 D-0.3866 D^{2}+0.001341 D^{3}
$$

The cubic regression model curve representing the behaviour of hardness concerning the immersion time is represented by Fig. 5, which indicates a drop in the hardness value with the increase in the immersion time as explained with reasons earlier in the article. 


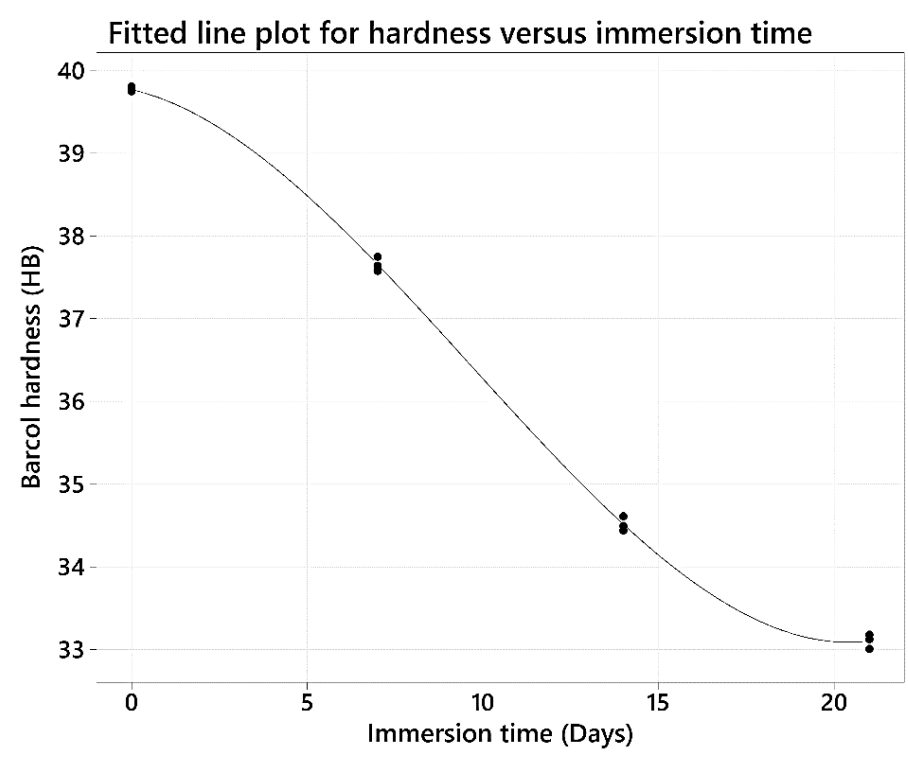

Fig. 5: Cubic regression model curve representing the effect of ageing on the hardness of nanocomposites.

\section{CONCLUSION}

The presented work focused on developing a cellulose fibre reinforced polymer layered silicate nanocomposite and testing the effect of ageing on its durability. The pinewood material contributed towards the required cellulose component, and high-density polyethene (HDPE) was used as the base polymer. The montmorillonite nanoclay was also added to make the complete nanocomposite. Hardness is a property of interest for most researchers, as it is believed to be a function of a tribological characteristic of the material, and is considered as the measure of durability in the presented work. The material is studied for the ageing condition, wherein it is immersed in tap water condition for 21 days. The hardness is quantified using Barcol hardness number. The study indicates that there is a significant effect of immersion time, in other words, ageing on the hardness (durability) of the developed nanocomposites. The one-way ANOVA results conducted at a $95 \%$ confidence interval indicates that the immersion time contributes $99.6 \%$ towards the variance in the hardness of the developed composites. The phenomenon that took place is due to (i) initially, the water absorption by the hygroscopic pinewood material, followed by (ii) the interfacial degradation, causing a further increase in water absorption. The thickness swelling phenomenon observed and analysed using Fourier equation validates the conclusive remarks.

\section{ACKNOWLEDGEMENT}

We would like to thank Ms Jaya Letchumi for helping us translate the abstract from English to Bahasa Melayu as per the requirement from the journal.

\section{REFERENCES}

[1] Bafna A, Beaucage G, Mirabella F, Mehta S. (2003) 3D hierarchical orientation in polymerclay nanocomposite films. Polymer, 44(4): 1103-1115. doi: 10.1016/S0032-3861(02)008339.

[2] Osman MA, Rupp JEP, Suter UW. (2005) Tensile properties of polyethylene-layered 
silicate nanocomposites. Polymer, 46(5): 1653-1660. doi: 10.1016/j.polymer.2004.11.112.

[3] Tanniru M, Yuan Q, Misra RDK. (2006) On significant retention of impact strength in clayreinforced high-density polyethylene (HDPE) nanocomposites. Polymer, 47(6): 2133-2146. doi: 10.1016/j.polymer.2006.01.063.

[4] Jamal NA. (2010) A Linear Relationship between the Mechanical, Thermal and Gas Barrier Properties of MAPE Modified Rubber Toughened Nanocomposites. IIUM Engineering Journal, 11(2): 225-239. doi: 10.31436/iiumej.v11i2.114.

[5] Chrissafis K, Paraskevopoulos KM, Tsiaoussis I, Bikiaris D. (2009) Comparative study of the effect of different nanoparticles on the mechanical properties, permeability, and thermal degradation mechanism of HDPE. Journal of Applied Polymer Science, 14(3): 1606-1618. doi: 10.1002/app.30750.

[6] Faruk O, Matuana LM. (2008) Nanoclay reinforced HDPE as a matrix for wood-plastic composites. Composites Science and Technology, 68(9): 2073-2077. doi: 10.1016/j.compscitech.2008.03.004.

[7] Delhom CD, White-Ghoorahoo LA, Pang SS. (2010) Development and characterisation of cellulose/clay nanocomposites. Composites Part B: Engineering, 41(6): 475-481. doi: 10.1016/j.compositesb.2009.10.007.

[8] Sheshmani S, Ashori A, Hamzeh Y. (2010) Physical properties of polyethylene-wood fibreclay nanocomposites. Journal of Applied Polymer Science, 118(6): 3255-3259. doi: 10.1002/app.32623.

[9] Deka BK, Maji TK. (2011) Study on the properties of nanocomposite based on high density polyethylene, polypropylene, polyvinyl chloride and wood. Composites Part A: Applied Science and Manufacturing, 42(6): 6860693. doi: 10.1016/j.compositesa.2011.02.009.

[10] Hossen MF, Hamdan S, Rahman MR, Rahman MM, Liew FK, Lai JC. (2015) Effect of fibre treatment and nanoclay on the tensile properties of jute fibre reinforced polyethylene/clay nanocomposites. Fibers and Polymers, 16(2): 479-485. doi: 10.1007/s12221-015-0479-x.

[11] Eshraghi A, Khademieslam H, Ghasemi I. (2016) Effect of weathering on physical and mechanical properties of hybrid nanocomposite based on polyethylene, woodflour and nanoclay. Maderas: Ciencia y Tecnologia, 18(4): 617-626. doi: 10.4067/S0718$221 \mathrm{X} 2016005000054$.

[12] Hossen MF, Hamdan S, Rahman MR, Islam MS, Liew FK, Lai JC, Rahman MM. (2017) Improved thermal properties of jute fibre-reinforced polyethylene nanocomposites. Polymer Composites, 38(7): 1266-1272. doi: 10.1002/pc.23691.

[13] Abd El-Fattah A, Abd ElKader E. (2018) Influence of different clays on the mechanical, thermal, and water absorption properties of recycled high-density polyethylene/wood flour hybrid composites. Journal of Composite Materials, 52(9): 1215-1226. doi: $10.1177 / 0021998317723180$.

[14] Zhu B, Wang X, Zeng Q, Wang P, Wang Y, Liu C, Shen, C. (2019) Enhanced mechanical properties of biodegradable poly( $\varepsilon$-caprolactone)/cellulose acetate butyrate nanocomposites filled with organoclay. Composites Communications, 13: 70-74. doi: 10.1016/j.coco.2019.03.002.

[15] Hossen MF, Asraf MA, E-Zahan MK, Haque MM, Zamir R, Zakaria RM. (2020) Optimisation of Nanoclay Loading on the Thermo-mechanical Behavior of Chemically Treated Jute Polyethylene Nanocomposites. Journal of Materials Science Research and Reviews, 5(3): 1-12.

[16] Faraji G, Kim HS, Kashi HT. (2018) Mechanical Properties of Ultrafine-Grained and Nanostructured Metals. Severe Plastic Deformation. Elsevier; pp. 223-257.

[17] Di Gianfrancesco A. (2017) Technologies for chemical analyses, microstructural and inspection investigations. Materials for Ultra-Supercritical and Advanced Ultra-Supercritical Power Plants. Elsevier; pp. 197-245.

[18] Stachowiak GW, Batchelor AW, Stachowiak GB. (2004) Simulation of wear and friction. Tribology Series, 44: 13-23.

[19] Adhikary KB, Pang S, Staiger MP. (2008) Long-term moisture absorption and thickness swelling behaviour of recycled thermoplastics reinforced with Pinus radiata sawdust. Chemical Engineering Journal, 142(2): 190-198. doi: 10.1016/j.cej.2007.11.024. 
[20] Atiqah A, Jawaid M, Ishak MR, Sapuan SM. (2017) Moisture Absorption and Thickness Swelling Behaviour of Sugar Palm Fibre Reinforced Thermoplastic Polyurethane. Procedia Engineering, 184: 581-586, 2017, doi: 10.1016/j.proeng.2017.04.142.

[21] Hoefsloot HCJ, Vis DJ, Westerhuis JA, Smilde AK, Jansen JJ. (2009) Multiset Data Analysis: ANOVA Simultaneous Component Analysis and Related Methods. Comprehensive Chemometrics. Volume 2. Elsevier; pp. 453-472.

[22] Christensen R. (2001) Analysis of Variance and Generalised Linear Models. International Encyclopedia of the Social \& Behavioral Sciences. Elsevier; pp. 473-480. 